April 1999

\title{
Embedded Metapragmatics and Lying Politicians
}

Stanton Wortham

University of Pennsylvania, stanton.wortham@bc.edu

Michael Locher

University of Chicago

Follow this and additional works at: https://repository.upenn.edu/gse_pubs

\section{Recommended Citation}

Wortham, S., \& Locher, M. (1999). Embedded Metapragmatics and Lying Politicians. Retrieved from https://repository.upenn.edu/gse_pubs/86

Postprint version. Published in Language and Communication, Volume 19, Issue 2, April 1999, pages $109-125$.

Publisher URL: http://dx.doi.org/10.1016/S0271-5309(98)00021-4

This paper is posted at ScholarlyCommons. https://repository.upenn.edu/gse_pubs/86

For more information, please contact repository@pobox.upenn.edu. 


\title{
Embedded Metapragmatics and Lying Politicians
}

\begin{abstract}
A metapragmatic expression denotes an event of speaking. An embedded metapragmatic construction embeds one metapragmatic expression within another, as in "Bush said Clinton lied." This article reports that embedded metapragmatic constructions, when used in television news coverage of U.S. political campaigns, most often predicate on the topic of lying. Simple metapragmatic constructions in this news coverage rarely describe lying, but embedded metapragmatic constructions often do. The article suggests two explanations. First, embedded metapragmatic constructions provide particularly rich opportunities for characterizing and evaluating the quoted speakers. Second, these constructions allow the reporter to make highly charged evaluations of the second embedded speaker, while placing the responsibility for such evaluations on the first embedded speaker. The article provides evidence to support these hypotheses, using as data the embedded metapragmatic constructions uttered on weekday newscasts on two networks, in the two months preceding the U.S. presidential elections in 1992 and 1996.
\end{abstract}

In recent years reporters have become increasingly bold in accusing politicians of lies and other moral transgressions (Wilson, 1990 and Patterson, 1993). Patterson documents how this adversarial and accusatory stance by the press has increased over the past four decades. In the 1960 US presidential campaign, for instance, 75\% of stories about the candidates reported "good" news. By the 1992 US presidential campaign this figure had fallen to $40 \%$. At the same time, however, the press still claims to be even-handed in reporting on politicians (Davis and Walton, 1983 and Waugh, 1995). Mainstream reporters do not want to express clear bias toward one political party, nor do they want to make unsubstantiated accusations. Reporters thus face a delicate situation when handling partly-substantiated allegations about politicians' lies or other moral transgressions - a situation which they face regularly in contemporary US political campaigns. The press wants to report this kind of story, but they do not themselves want to be accused of bias or of making unwarranted allegations.

This article describes how reporters sometimes solve this problem with recourse to a particular type of linguistic construction, which we have called "embedded metapragmatics" (Locher and Wortham, 1994). In an embedded metapragmatic construction the speaker reports what one speaker says about another's language use, as when a reporter says "Bush claimed that Clinton lied". This article provides evidence that reporters often use such embedded metapragmatic constructions to report allegations about politicians' lies and other moral transgressions. We explain this fact by describing how the construction allows reporters to express allegations against politicians without themselves taking responsibility for those allegations. When the accusation of lying is placed in the mouth of the embedded speaker (Bush's mouth, in the example above), the reporter becomes in Goffman (1979)'s terms merely the "animator" uttering the message and not the "principal" responsible for the content of the accusation.

The article fleshes out this account of embedded metapragmatics and politicians' lies by examining television network news coverage of the 1992 and 1996 US presidential campaigns. The first section of the article describes our approach to the social functions of language, which draws heavily on Bakhtin, and gives a more formal account of embedded metapragmatic constructions. The second section first describes the methods we used in collecting and analyzing network news coverage of the 1992 and 1996 US presidential campaigns. This section then reports the central result from our data analysis - that almost half the embedded metapragmatic constructions used by reporters describe events of lying or other moral transgressions by politicians - and presents two hypotheses to explain this finding. This section goes on to describe a more specific pattern in the data that shows how reporters use embedded metapragmatic constructions to avoid responsibility for accusations about political lies: the verb of lying virtually always appears in the second embedded slot. That is, reporters almost never make statements 
like "Bush lied about Clinton's claim", but they often make statements like "Bush claimed that Clinton lied". The last section draws conclusions about the ubiquitous social functions of language use and how these affect political reporting.

\section{Keywords}

metapragmatics, voice, double voicing, news discourse, media bias

\section{Comments}

Postprint version. Published in Language and Communication, Volume 19, Issue 2, April 1999, pages 109-125.

Publisher URL: http://dx.doi.org/10.1016/S0271-5309(98)00021-4 


\title{
Embedded Metapragmatics and Lying Politicians
}

\author{
Stanton Wortham \\ University of Pennsylvania \\ Graduate School of Education \\ 3700 Walnut Street \\ Philadelphia, PA 19104-6216 \\ USA \\ (215) 898-6307 \\ FAX (215) 898-4399 \\ stantonw@gse.upenn.edu \\ Michael Locher \\ University of Chicago \\ mlocher@yahoo.com
}

Short Title: Embedded metapragmatics

Keywords: metapragmatics, voice, double voicing, news discourse, media bias

Size: 7833 words, including notes and references; $107 \mathrm{~KB}$ 


\begin{abstract}
A metapragmatic expression denotes an event of speaking. An embedded metapragmatic construction embeds one metapragmatic expression within another, as in "Bush said Clinton lied." This article reports that embedded metapragmatic constructions, when used in television news coverage of U.S. political campaigns, most often predicate on the topic of lying. Simple metapragmatic constructions in this news coverage rarely describe lying, but embedded metapragmatic constructions often do. The article suggests two explanations. First, embedded metapragmatic constructions provide particularly rich opportunities for characterizing and evaluating the quoted speakers. Second, these constructions allow the reporter to make highly charged evaluations of the second embedded speaker, while placing the responsibility for such evaluations on the first embedded speaker. The article provides evidence to support these hypotheses, using as data the embedded metapragmatic constructions uttered on weekday newscasts on two networks, in the two months preceding the U.S. presidential elections in 1992 and 1996.
\end{abstract}


In recent years reporters have become increasingly bold in accusing politicians of lies and other moral transgressions (Wilson 1990; Patterson 1993). Patterson documents how this adversarial and accusatory stance by the press has increased over the past four decades. In the 1960 U.S. presidential campaign, for instance, seventy-five percent of stories about the candidates reported "good" news. By the 1992 U.S. presidential campaign this figure had fallen to forty percent. At the same time, however, the press still claims to be even-handed in reporting on politicians (Davis \& Walton 1983; Waugh 1995). Mainstream reporters do not want to express clear bias toward one political party, nor do they want to make unsubstantiated accusations. Reporters thus face a delicate situation when handling partly-substantiated allegations about politicians' lies or other moral transgressions — a situation which they face regularly in contemporary U.S. political campaigns. The press wants to report this kind of story, but they do not themselves want to be accused of bias or of making unwarranted allegations.

This article describes how reporters sometimes solve this problem with recourse to a particular type of linguistic construction, which we have called "embedded metapragmatics" (Locher \& Wortham 1994). ${ }^{1}$ In an embedded metapragmatic construction the speaker reports what one speaker says about another's language use, as when a reporter says "Bush claimed that Clinton lied." This article provides evidence that reporters often use such embedded metapragmatic constructions to report allegations about politicians' lies and other moral transgressions. We explain this fact by describing how the construction allows reporters to express allegations against politicians without themselves taking responsibility for those allegations. When the accusation of lying is placed in the mouth of the embedded speaker (Bush's mouth, in the example above), the reporter becomes in Goffman's (1979) terms merely the "animator" uttering the message and not the "principal" responsible for the content of the 
accusation.

The article fleshes out this account of embedded metapragmatics and politicians' lies by examining television network news coverage of the 1992 and 1996 U.S. presidential campaigns. The first section of the article describes our approach to the social functions of language, which draws heavily on Bakhtin, and gives a more formal account of embedded metapragmatic constructions. The second section first describes the methods we used in collecting and analyzing network news coverage of the 1992 and 1996 U.S. presidential campaigns. This section then reports the central result from our data analysis—-that almost half the embedded metapragmatic constructions used by reporters describe events of lying or other moral transgressions by politicians_—and presents two hypotheses to explain this finding. This section goes on to describe a more specific pattern in the data that shows how reporters use embedded metapragmatic constructions to avoid responsibility for accusations about political lies: the verb of lying virtually always appears in the second embedded slot. That is, reporters almost never make statements like "Bush lied about Clinton's claim," but they often make statements like "Bush claimed that Clinton lied." The last section draws conclusions about the ubiquitous social functions of language use and how these affect political reporting.

\section{Double voicing and embedded metapragmatics}

Linguistic work from several traditions_e.g., systemic functional linguistics (Halliday 1994; Lemke 1998), linguistic anthropology (Gumperz 1982; Silverstein 1993) and the analytic philosophy of language (Austin 1956/1975)—-has shown that speech always positions the speaker socially. Whatever they say, speakers inevitably give off cues about their position with respect to others in the speech situation, cues about their position with respect to types of people 
in the social world, and/or cues about their position with respect to the ideational content that their utterances convey. Bakhtin (1935/1981, 1953/1986, 1963/1984) provides an important early theory of this social positioning, which he calls a "dialogic" approach to language. Bakhtin's dialogic approach underlies our analyses of reporters' language use.

Most analyses, Bakhtin argues, treat language use as "monologic." Monologic discourse is "the word of no one in particular" (1935/1981:276)—it acts as if the social position of the speaker is irrelevant to its meaning. Monologic approaches to language assume that we can understand a speaker's meaning with reference only to the structure and content of that speaker's utterance, independent of the speaker's relations with others. Consider the following example: a government spokesperson, reporting events in an ongoing war, who says that "there was some collateral damage yesterday." From a monologic point of view, we would understand this utterance by interpreting the denotational content it carries. "Collateral damage" is a military euphemism for 'unintended civilian casualties,' so the spokesperson is referring to civilian casualties suffered the day before.

For Bakhtin such monologic approaches can never suffice. "The expression of an utterance can never be fully understood or explained if its thematic content is all that is taken into account. The expression of an utterance always responds to a greater or lesser degree, that is, it expresses the speaker's attitude towards others' utterances and not just his attitude toward the object of his utterance" (1953/1986:92). An utterance does almost always denote something, but it also almost always contributes to the speaker's position with respect to others—and this social positioning is essential to the meaning of the utterance. In order to understand this point of Bakhtin's more systematically, we must first make a central distinction between what Jakobson (1957/1971) calls the "event of speaking" and the "narrated event." We will modify 
this terminology slightly, and refer to the event of speaking as the "narrating" event. The narrating event is the interactional event within which the speaker utters something, whether this be a government briefing, a classroom conversation, a news report, or whatever. The narrated event is the event described as the content of the utterance, like the "collateral damage" described in the example above. Bakhtin's point, put simply, is that we cannot fully understand narrated content without taking into account various aspects of the narrating event in which it occurs.

Figure 1 represents this distinction between narrating and narrated.

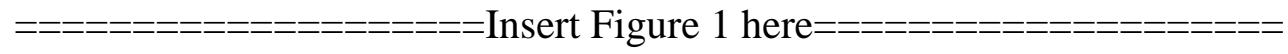

The larger rectangle represents the narrating event, within which the government spokesperson is speaking. The embedded rectangle represents the narrated event. A monologic approach to utterance meaning would focus only on the narrated event, note that "collateral damage" refers euphemistically to 'civilian casualties,' and stop the interpretation there. Bakhtin, on the other hand, is also interested in "the speaker's attitude toward others' utterances." In this case, he would probably note first that "collateral damage" is a phrase associated with certain types of speakers_-particularly those connected to the military, who often present dead civilians as an unintended but inevitable consequence of war. The figure marks this indexical connection with the dotted line connecting "collateral damage" to military strategists and spokespeople. ${ }^{2}$ Note that this latter group is represented in the narrating event. They need not be physically present in the briefing room, because they are part of the interactional world known and inhabited by everyone in the narrating event itself. The figure also represents, in the narrating event, potential critics of military action that endangers civilians. These too-even if they are not actually present in the briefing room—are indexed by the phrase "collateral damage," as the group 
opposed to the military's acceptance of civilian casualties.

For Bakhtin, in order to understand what the speaker means by the narrated utterance we must understand what position the briefer is taking up with respect to the military and the critics in the narrating event. Does the speaker use this phrase in a straightforward referential way, as military personnel generally do? If so, how would the speaker respond to those who decry such usage as a euphemism for the evils of war? Does the speaker use the phrase instead in a mocking or ironic way, and thus place him or herself against politicians or soldiers who use the phrase merely referentially? These questions describe a rudimentary "dialogue" opened by the use of that one phrase. In order fully to understand the meaning of the phrase as uttered by this particular speaker, we must understand where the speaker is positioning him or herself interactionally with respect to members of those other groups—as if the speaker were entering a dialogue with those other people.

For Bakhtin, then, any speaker almost inevitably enters into a dialogue of social positioning whenever he or she speaks. Bakhtin develops this insight through his central concept of voice. He begins his definition of "voice" by observing the "internal stratification" of language, which he also calls "heteroglossia" (1935/1981:263). Heteroglossia is the natural state of language, where any given language contains within itself forms associated with a wide variety of social groups.

Language has been completely taken over, shot through with intentions and accents....All words have the "taste" of a profession, a genre, a tendency, a party, a particular work, a particular person, a generation, an age group, the day and hour. Each word tastes of the context and contexts in which it has lived its socially charged life. (1935/1981:293) 
The social world is composed of many, overlapping social groups—religious groups, political groups, ethnic groups, and so on. These groups can be defined by social position and by ideological commitments. "Certain features of language take on the specific flavor" of particular groups (1935/1981:289). "Collateral damage," for instance, is associated with military personnel and aficionados. In speaking we inevitably use words that have been used by others, words that "taste" of or index the social locations and ideological commitments carried by those earlier uses. The association between particular words and particular social locations—an association we now analyze as indexical presupposition (Silverstein 1976)—provides one type of structure always in play when we speak. Speaking with a certain "voice," then, means using words that index some position(s), because these words are characteristically used by members of a certain group. A voice is a social position, from the stratified world, as indexed by stratified language.

When a speaker utters words that have been used by and thus "taste" of socially identifiable others, at least two voices are in play: the type of person who habitually uses these words, and the speaker him or herself. Bakhtin describes the duality of this situation with the concept of "double voicing." Double voiced discourse "has a twofold direction—it is directed both toward the referential object of speech, as in ordinary discourse, and toward another's discourse, toward someone else's speech" (1963/1984:185). In double voiced discourse the speaker's meaning emerges in part through an interaction with the voice of another, who also speaks through the current speaker's words. In double voiced discourse "a conflict takes place," as the speaker layers his own intonations over the still live words of another (1963/1984:74).

Bakhtin first developed his account of double voicing in his work on the novel. In his seminal work on Dostoevsky, Bakhtin calls double voiced discourse "the chief subject of our 
investigation, one could even say its chief hero" (1963/1984:185). Bakhtin (1935/1981) argues that novels rely centrally on double voiced discourse. The following simple illustration comes from Dickens' Little Dorrit:

It was a dinner to provoke an appetite, though he had not had one. The rarest dishes, sumptuously cooked and sumptuously served; the choicest fruits, the most exquisite wines; marvels of workmanship in gold and silver, china and glass; innumerable things delicious to the senses of taste, smell, and sight were insinuated into its composition. $O$, what a wonderful man this Merdle, what a great man, what a master man, how blessedly and enviably endowed — in one word, what a rich man! (book 2, chapter 12; quoted in Bakhtin 1935/1981:304; emphasis Bakhtin's)

In Bakhtin's analysis, this passage begins with a "parodic stylization of high epic style." The first two sentences might echo the thoughts of Merdle himself—-Merdle the self-satisfied businessman, who fancies himself as important as royalty. The italicized portion is "a chorus of his admirers in the form of the concealed speech of another." These words echo with the voice of Merdle's hypocritical admirers, who sing his praises only because they want to share in his wealth and fame. Bakhtin calls the last seven words "authorial unmasking." Here Dickens replaces all the earlier praises with the single word "rich," and thus shows the irony of Merdle's view of himself and the hypocrisy of his sycophants.

In this passage Dickens juxtaposes at least three voices: Merdle, his admirers, and those like Dickens himself who appreciate the irony of the situation. Figure 2 represents this account.

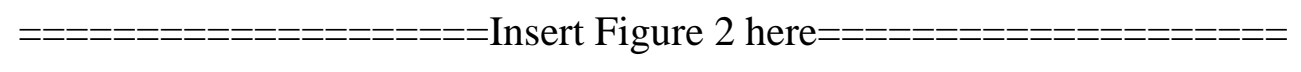

Within the narrated event, we have Merdle and his fawning admirers. These characters are 
described using cues_-largely a modified form of quoted speech ("indirect freestyle"), which represents the thoughts or words of characters as if they were being spoken-that index certain groups in the socially stratified world: self-satisfied businessmen and their sycophants. Dickens himself also adopts a position in the narrating event, with respect to those two other groups, by laughingly exposing their hypocrisy. In this passage Dickens' descriptions are double voiced, because they evoke the voices of successful businessmen and their sycophants and also position Dickens' own voice with respect to these others. The voices of the characters and the author have a metaphorical dialogue. In this case the dialogue is relatively simple: self-satisfied businessmen like Merdle admire themselves for their worldly success; their sycophants admire them for this too; this admiration from others makes the businessmen admire themselves even more; but people like Dickens think this admiration is ridiculous and really a disguise for base materialist motives.

Note that Dickens makes his point in this passage by positioning himself with respect to others in the narrating event, not by denoting it explicitly. Bakhtin's concepts of voice and double voicing provide useful tools for exploring the social positioning that happens in all speech. Whether they intend to or not, speakers always use linguistic forms that presuppose voices from the social world. And, whether they intend to or not, speakers always position themselves with respect to those presupposed voices. This process of positioning — or voicing and double voicing — can be seen most clearly in the phenomenon of quoted speech. Both Bakhtin and Vološinov (1929/1986) describe quotation as one device which allows speakers to introduce and evaluate other voices. By placing words into the mouth (or mind) of another speaker we can give that speaker a certain voice, as Dickens did for Merdle's sycophants with the passage that begins "oh what a wonderful man this Merdle...". And by framing quoted speech with 
metapragmatic verbs, speakers can both voice the quoted speakers and express their own attitude toward those speakers. Framing a quotation with "he declared," for instance, likely presupposes different voices for narrating and narrated speakers than framing the same quotation with "he wheedled." So quoted speech, as noted by various contemporary linguistic anthropologists since Bakhtin (e.g., Besnier 1992; Parmentier 1993; Silverstein 1993), provides a particularly rich resource for voicing and double voicing.

Some contemporary analyses of quoted speech in media discourse assume that, while indirect quotation inevitably involves positioning by the quoting speaker, direct quotation can provide relatively objective representations of what another said (e.g., Gibson \& Zillman 1993). Gibson and Zillman report that journalists are encouraged to use direct quotation for this reason and that audiences often interpret direct quotation as being more accurate. From a Bakhtininan perspective, however, even direct reported speech involves and communicates the social position of the speaker. Contemporary linguistic analyses of reported speech agree with Bakhtin and Vološinov that all quotation involves voicing and double voicing-in the selection of the particular quote and in the co-textual framing of that quote (Besnier 1992; Clark \& Gerrig 1990; Parmentier 1993; Waugh 1995). ${ }^{3}$ All quotation involves selection and "filtering" (Waugh 1995), or the "leakage" of the quoting voice onto the quoted (Besnier 1992).

If quoted speech provides a particularly rich resource for voicing and double voicing, embedded metapragmatic constructions have even more potential. Embedded metapragmatic constructions embed one quote within another, and thus provide the opportunity to voice and double voice two speakers and the relationship between those speakers. For instance, "Bush suggested that Clinton had failed to tell the truth" is an embedded metapragmatic construction, and the reporter using such a construction has an opportunity to voice both Bush and Clinton and 
the relationship between them. Generally, embedded metapragmatic constructions take the following form, with the bracketed components optional:

Speaker $_{1}$ Metapragmatic expression $_{1}\left[\left[\right.\right.$ to $\left._{\text {Hearer }}\right]$ [that] Speaker ${ }_{2}$ Metapragmatic expression $_{2}\left[[\right.$ to $]$ Hearer $\left._{2}\right]$ [[that] Utterance]

The defining feature of embedded metapragmatic constructions is that Speaker $_{2}$ and

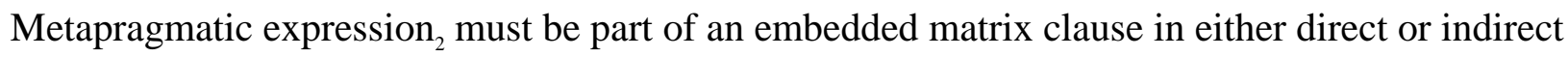
discourse. Note that multiple perspectives coexist in embedded metapragmatic constructions. Singly-embedded metapragmatic constructions can contain three distinct perspectives: the narrator's, Speaker ${ }_{1}$ 's, and Speaker ${ }_{2}{ }^{\prime}{ }^{4}$

Figure 3 represents an embedded metapragmatic construction, using the format introduced above. This particular quotation—-Bush also suggested that Clinton had failed to tell the truth about who he met during a trip to Moscow"— comes from ABC News on October 8, 1992. We analyze this example in more detail in the next section.

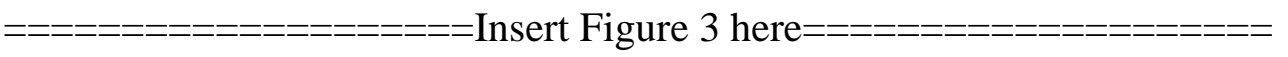

In the narrating event a reporter carries on a conversation with the anchor of the newscast, a conversation directed at the viewing audience. In the outermost narrated event, as described by the reporter, George Bush (speaker ${ }_{1}$ ) makes a suggestion (metapragmatic expression ) $_{1}$. Bush does so as part of a particular interactional event, in this case a televised interview with Larry King. In the embedded narrated event, as the reporter describes Bush describing it, Bill Clinton $\left(\text { speaker }_{2} \text { ) failed to tell the truth (metapragmatic expression }\right)_{2}$ ) when questioned by an interviewer about his activities during the Vietnam War. By using this type of construction, the reporter has the opportunity to voice Bush—as the type of person who "suggests" that his political opponents were communist sympathizers in the sixties. He or she also has the opportunity to voice Clinton, 
perhaps as the type of person who repeatedly has to defend himself against allegations of lying and moral transgressions. Both these types of voicing can be double voiced, for instance if the reporter positions him or herself as disgusted by the types of negative campaigning and doublespeak practiced by politicians like Bush and Clinton. ${ }^{5}$ As discussed in more detail in the next section, the reporter can also evade responsibility for the double voicing of Clinton by placing the quotation of speaker $_{2}$ in the mouth of speaker $_{1}$.

Goodwin (1990) has described a type of embedded metapragmatic construction common among the American black girls she studied. This construction occurs in disputes over gossip. The girls call it "he-said-she-said." This construction fits the definition of embedded metapragmatics because it presupposes three events of speaking: a confrontation between two speakers (A \& B), in which A accuses B of gossiping about her behind her back; a prior conversation in which a third party (C) told A that B engaged in gossip about A; and the precipitating event, in which B gossiped about A in the presence of C. Goodwin offers the following example: "they [C] say y'all [B] say I [A] wrote everything over there." As one might imagine, the disputes that center around such utterances can have serious consequences for relationships among these girls.

While structurally similar to the embedded metapragmatic constructions reporters use, he-said-she-said constructions have different interactional implications because of the first speaker's (A's) direct involvement in both other presupposed events of speaking. In the first embedded event $\mathrm{C}$ reports the gossip to $\mathrm{A}$, and in the second embedded event $\mathrm{A}$ is the target of the gossip (i.e., A was central to the narrated content in the innermost event). For purposes of comparison, let us represent a reporter's embedded metapragmatic construction thus: [D reports that (candidate E suggested \{candidate F lied\})]. ${ }^{6}$ In such a construction, the reporter D was 
often in the audience that heard $\mathrm{E}$ make his or her accusation (like A in the cases described by Goodwin). But reporters almost always distance themselves from any involvement in the second embedded narrated event, although they might gather independent evidence to support or undermine E's allegation about F's utterance because they want to present a factual, objective report. F's alleged lie, then, happens independent of the reporter D. For this reason reporters generally do not intend their embedded metapragmatic utterances to have implications for their relationships with candidates E or F, while among Goodwin's girls A explicitly intends her utterance to have implications for her relationships with B and C.

The particular configuration of reporters' embedded metapragmatic utterances, we argue, comes from the social position they occupy. As described above, reporters today seem to relish reporting "bad" news, and particularly bad news about politicians' lies and other moral transgressions (cf. Glasgow University Media Group 1980; Patterson 1993). But a highly charged accusation of lying also carries risk for a reporter. Political reporters attempt to be neutral in their coverage of political campaigns (Davis et al. 1983), and they want to claim that their utterances are simple reference, epistemically warranted (Waugh 1995). Except in those rare cases where they have incontrovertible evidence supporting the allegation, reporters do not want to appear biased in their presentation of candidates' alleged lies. Embedded metapragmatic constructions help solve this problem. These constructions allow the reporter to present the allegation that a candidate lied, while placing responsibility for the allegation on another speaker.

\section{Political lies}

To investigate whether or not reporters do in fact use embedded metapragmatic 
constructions this way, we have identified all embedded metapragmatic constructions used on weekday broadcasts of two U.S. national network news programs (ABC World News Tonight and CBS Evening News) between Labor Day and Election Day in 1992 and 1996. Other research has shown that about $20 \%$ of television news copy is quoted speech (Glasgow University Media Group 1980). Embedded metapragmatic constructions, while regularly used, are much less common. We counted 370 embedded metapragmatic constructions in the 168 election-year newscasts in our data, an average of about 2.2 per day. ${ }^{7}$ Most interesting, from our point of view, $43 \%$ of those embedded metapragmatic constructions involved metapragmatic expressions describing lying and another $28 \%$ involved metapragmatic expressions describing other sorts of moral transgressions by political candidates.

Why do so many embedded metapragmatic expressions describe events of lying and other moral transgressions? We offer two complementary explanations for this pattern. First, embedded metapragmatic constructions provide particularly rich potential for characterizing and evaluating (i.e., voicing and double voicing) the quoted speakers. Accusations about lying can be dramatic political news, and reporters draw on the most powerful devices they can in presenting this topic. Second, and perhaps more importantly, these constructions allow reporters to describe highly charged evaluations of the second embedded speaker ( speaker $_{2}$, or candidate F), while placing the responsibility for such evaluations on the first embedded speaker. Thus reporters appear neutral, while nonetheless reporting politicians' alleged lies.

We will illustrate these two explanations with reference to the following examples of embedded metapragmatic constructions, taken from $\mathrm{ABC}$ news coverage of campaign events on October 8, 1992:

Bush also suggested that Clinton had failed to tell the truth about who he met during a 
trip to Moscow in $1969 \ldots$.

Clinton's running mate launched a sharp counter-attack, accusing the President of planting suspicions the way Senator Joe McCarthy did....

The Bush campaign refused to back down, saying Clinton has given conflicting accounts. Although these are only fragments of a larger report, they present the core of the story. These embedded metapragmatic constructions allow the reporter to represent concisely the "spin" favored by each side in the campaign . In Bakhtin's terms, the constructions allow the reporter to represent the voicing and double voicing that each side is giving for themselves and the opponent. Some of this is simply good reporting. The power of quotation and embedded metapragmatic constructions allows the reporter to present concise summaries of how Bush tries to take the moral high ground and question Clinton's judgment, while Clinton also claims the moral high ground and presents Bush as running a smear campaign.

In addition to reporting the struggle over voicing and double voicing being done by the campaigns, the reporter also provides some voicing for the candidates himself. He characterizes Gore's response in military terms—Gore "launched a sharp counter-attack, accusing the President of planing suspicions." And he also characterizes the Bush campaign's response in terms often used to describe physical or military conflict—-they "refused to back down." Thus he presupposes that this political campaign is like a physical or military conflict, even though the statements actually made by the Bush and Clinton campaigns would undoubtedly also have supported alternate characterizations . For instance, instead of "politics-as-war" we could have had "politics-as-beauty-contest," or "politics-as-chess-match," etc. Elsewhere we give more 
detailed analyses of the extensive voicing and ventriloquation done by $\mathrm{ABC}$ reporters in this particular story (Locher et al. 1994) and analyses of how other reporters engage in similarly intricate voicing and ventriloquation (Wortham \& Locher 1996). These detailed examinations show how reporters portray many politicians as morally questionable types of people, and how they position themselves as defenders of the public good, in a position above the immoral politicians. Our studies provide more detailed empirical illustrations of the increasing tendency, sketched by Patterson (1993), for reporters to question politicians' moral character.

Embedded metapragmatic constructions provide one central tool (among many others) for reporters to question politicians' ethics while remaining themselves above the fray. Note how, in the above example, the embedded metapragmatic constructions allow the reporter to present Clinton's alleged lies and Bush's McCarthyism without the reporter himself taking responsibility for these characterizations. As mentioned above the second, embedded metapragmatic characterization in these constructions generally presupposes a distinction made by Goffman (1979) between the animator (the person uttering the message) and the principal (the person responsible for the substance of the message). Embedded metapragmatic constructions present reporters simply as animators of any embedded allegations about lying or other moral transgressions, with the first embedded speaker (speaker ${ }_{1}$ ) as the principal. In the example above Bush is clearly the principal responsible for saying Clinton lied, and Gore is the principal responsible for saying that Bush practices McCarthyism. Through his use of the embedded metapragmatic construction, the reporter claims merely to animate these accusations about immoral acts.

In her account of verbal defamation in a Wolof village, Irvine (1992) gives a systematic account of how speakers can avoid responsibility for morally questionable verbal behavior. 
First, she notes that "in acts of verbal abuse, there are two levels at which conduct is questionable: the reprehensible behavior or condition alleged to be the case and predicated of someone other than the speaker; and the speaker's act of making the allegation, an act that might itself be reprehensible under some circumstances" (105). Wolof villagers who point out others' transgressions might themselves be engaged in immoral acts if they do so in an inappropriate manner, just as political reporters might be accused of bias or of making unsubstantiated allegations when they report politicians' moral transgressions. On Irvine's account, in order to get away with an insult a speaker must successfully deliver an allegation about the insulted person (by describing something reprehensible as the narrated event) and avoid responsibility for making an inappropriate utterance (in the narrating event). She describes three ways in which speakers can evade responsibility and leave themselves "lines of retreat" should they be challenged: dissociating the speaker from the author or principal of the insult; framing the insult as not fully serious; or making the insult semantically oblique, by (e.g.) expressing it as a metaphor. Reporters using embedded metapragmatic constructions rely on the first of these strategies. They do utter the accusation about a politician's lies or other moral transgressions, but they present it as the utterance and responsibility of the first embedded speaker. Thus embedded metapragmatic constructions allow reporters to report on political lies while defending their objectivity.

One further pattern in the data, in addition to the disproportionate use of this construction to report events of lying, supports our claim that embedded metapragmatic constructions function in part to shield reporters from accusations of bias when they include politicians' alleged moral transgressions in their stories. Reporters virtually always place the metapragmatic descriptions of lying and other moral transgressions in the mouth of the second embedded 
speaker ( speaker $_{2}$ ). Table 1 represents this pattern.

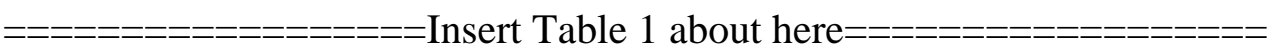

This table contains a representative sample ${ }^{8}$ of embedded metapragmatic constructions from the data set, and presents the first and second metapragmatic expressions for each instance. This representation allows us to see the types of metapragmatic descriptors used, and which types of expression reporters use in which slot.

Note first that all metapragmatic descriptors that describe lying (including waffle, flipflop, failure to come clean, etc.) occur as the second metapragmatic expression. As in the whole data set, just under half of the constructions describe an event of lying. Another quarter of the second metapragmatic expressions describe a type of speech event which only morally questionable speakers engage in (smear campaign, McCarthyism, etc.). Overall, then, over twothirds of the second expressions impugn the second embedded speaker's character. It is difficult to imagine grammatical reasons for this. One could easily imagine an utterance of the form "Bush lied about Clinton's past statements." But such utterances rarely occur in these television news reports.

Reporters use much less highly presupposing metapragmatic expressions in the first slot. That is, we know a lot less about the quoted speaker (speaker ${ }_{1}$ ) from the metapragmatic expressions used to describe speakers in this position. Say, for instance-the most minimally presupposing metapragmatic verb (Goossens 1982)_ occurs about one-third of the time in the first slot. ${ }^{9}$ Say virtually never occurs in the second slot. We explain this disproportionate use of minimally presupposing metapragmatic expressions in the first slot, and the disproportionate use of more highly presupposing expressions in the second slot, with reference to two facts about embedded metapragmatic constructions. (1) Speakers must take some responsibility for the 
choice of the first metapragmatic expression, because they selected that expression. ${ }^{10}$ Because reporters want to avoid the appearance of partisan bias and to avoid responsibility for

unsubstantiated allegations, they rarely use highly presupposing expressions in the first slot. (2) Expressions in the second slot, however, can be blamed on the first embedded speaker. The reporter is_-as illustrated graphically in Figure 3-insulated from the embedded narrated event by the intervening first embedded speaker. Thus the reporter can claim merely to animate speaker ${ }_{1}$ s message, even when he or she might be selecting more highly presupposing metapragmatic expressions than speaker ${ }_{1}$ in fact used.

\section{Conclusions}

In this article we have described two salient facts about political reporters' use of embedded metapragmatic constructions: they most often use these constructions to describe politicians' alleged lies or other moral transgressions; and they almost always describe these transgressions in the second, embedded slot of the construction. We have explained these facts in terms of the particular social position political reporters occupy. Unlike reporters in the 1950s and 1960s, they increasingly want to report about candidates' moral transgressions. But, like those past reporters, they want to present their stories as unbiased and epistemically warranted. They want, one might say, to combine the human interest of Geraldo with the trustworthiness of Walter Cronkite. Placing their accusations about politicians' transgressions in the second slot of an embedded metapragmatic construction allows reporters to accomplish these twin goals.

If confronted with these findings, reporters would likely respond that they are merely telling the truth. Patterson (1993) asked leading reporters why they spend so much time reporting on politicians' alleged lies, and the overwhelming response was: "because politicians 
are in fact liars." In response to our findings about embedded metapragmatic constructions, reporters would likely claim that they merely report politicians' own accusations about each other. In one sense this is true. Political candidates do in fact accuse each other of lies and other moral transgressions on a regular basis. The press might bear some responsibility for encouraging this, but clearly politicians bear substantial responsibility as well. From our perspective, however, reporters cannot fully evade responsibility by claiming that they merely report the truth.

As described by Bakhtin and many others, speech— the primary medium of political reporting — inevitably positions both narrated characters and the narrating speaker. Bell (1991), van Dijk (1988), Verschueren (1985) and Wilson (1990) make this same point, using slightly different tools for analyzing language. One cannot help but attribute some voice or other to the narrated characters one describes, and one inevitably double voices these characters by taking up some stance with respect to them. This is as true of political reporters as it is of everyday narrators, teachers, lawyers, etc. When reporting the speech of politicians, reporters inevitably select from among the things politicians say. And they inevitably frame the selected quotations with metapragmatic expressions that often characterize and evaluate the politicians being quoted. Even in embedded metapragmatic expressions, in which reporters can claim merely to be animating others' accusations about politicians, the reporters do in fact select quotations and metapragmatic framing material that voice and double voice the second embedded speaker.

So we are not accusing political reporters of unprofessionally failing to maintain objectivity. If by "objective reporting" we mean a reporter who takes no social position at all in the narrating event, we would argue that such a thing cannot happen. ${ }^{11}$ We would not accuse reporters of failing to meet this unreasonable standard. As linguistic anthropologists we are 
interested, instead, in describing the social situation reporters find themselves in and the linguistic means they use to manage that situation. ${ }^{12}$ Given the twin demands for more sensational news and for objectivity, it seems a reasonable strategy (whether conscious or not) for reporters to use embedded metapragmatic constructions in describing alleged political lies. In this article we intend merely to show how this is a socially-motivated response to a particular social situation, not a means for reporting "the facts."

\section{References}

Austin, John (1956/1975). How to do things with words (2nd ed.). Cambridge, MA: Harvard University.

Bakhtin, Mikhail (1935/1981). Discourse in the novel (translated by Caryl Emerson and Michael Holquist). In Mikhail Bakhtin, The dialogic imagination, 259-422. Austin: University of Texas.

(1953/1986). The problem of speech genres (translated by Vern McGee). In Mikhail

Bakhtin, Speech genres \& other late essays, 60-102. Austin: University of Texas.

— (1963/1984). Problems of Dostoevsky's poetics (translated by Caryl Emerson).

Minneapolis: University of Minnesota.

Bell, Allan (1991). The language of news media. Cambridge, MA: Basil Blackwell. 
Besnier, Niko (1992). Reported speech and affect on Nukulaelae Atoll. In Jane Hill \& Judith Irvine (eds.), Responsibility and evidence in oral discourse, 161-181. New York: Cambridge University.

Clark, Herbert \& Gerrig, Richard (1990). Quotations as demonstrations. Language 66:764-805.

Davis, Howard \& Walton, Paul (eds.) (1983). Language, image, media. New York: St. Martin's.

Gibson, Rhonda \& Zillman, Dolf (1993). The impact of quotation in news reports on issue perception. Journalism Quarterly 70:793-800.

Glasgow University Media Group. (1980). More bad news. New York: Routledge. Goffman, Erving (1979). Footing. Semiotica 25:1-29.

Goodwin, Marjorie (1990). He-said-she-said. Bloomington: University of Indiana.

Goossens, Louis (1982). Say: focus on the message. In René Dirven, Louis Goossens, Yvan Putseys, Emma Vorlat (eds.), The scene of linguistic action and its perspectivization by speak, talk, say and tell, 85-131. Philadelphia: John Benjamins.

Gumperz, John (1982). Discourse strategies. New York: Cambridge University.

Halliday, Michael (1994). An introduction to functional grammar (2nd. ed.). London: Edward Arnold.

Irvine, Judith (1992). Insult and responsibility: Verbal abuse in a Wolof village. In Jane Hill \& Judith Irvine (eds.), Responsibility and evidence in oral discourse, 105-134. New York: Cambridge University.

Jakobson, Roman (1957/1971). Shifters, verbal categories, and the Russian verb. In Roman Jakobson, Selected writings (Vol. 2), 130-147. The Hague: Mouton. (1960). Closing statement: linguistics and poetics. In Thomas Sebeok (ed.), Style in 
language, 350-377. Cambridge, MA: MIT.

Lemke, Jay (1998). Resources for attitudinal meaning. Functions of Language 5:33-56.

Locher, Michael \& Wortham, Stanton (1994). The cast of the news. Pragmatics 4:517-534.

Mayes, Patricia (1990). Quotation in spoken English. Studies in Language 14:325-363.

Parmentier, Richard (1993). The political function of represented speech. In John Lucy (ed.), Reflexive language, 261-286. New York: Cambridge University.

Patterson, Thomas (1993). Out of order. New York: Knopf.

Rumsey, Alan (1990). Wording, meaning, and linguistic ideology. American Anthropologist 92:346-361.

Silverstein, Michael (1976). Shifters, linguistic categories, and cultural description. In Keith Basso \& Henry Selby (eds.), Meaning in anthropology, 11-55. Albuquerque: University of New Mexico.

(1992). The indeterminacy of contextualization: when is enough enough? In Aldo

DiLuzio \& Peter Auer (eds.), The contextualization of language, pp. 55-75. Philadelphia: John Benjamins.

(1993). Metapragmatic discourse and metapragmatic function. In John Lucy (ed.), Reflexive language. New York: Cambridge University.

Van Dijk, Teun (1988). News as discourse. Hillsdale, NJ: Lawrence Erlbaum.

Verschueren, Jef (1985). International news reporting. Philadelphia: John Benjamins. Vološinov, Valentin (1929/1986). Marxism and the philosophy of language (translated by Ladislav Matejka and I.R. Titunik). Cambridge, MA: Harvard University. Waugh, Linda (1995). Reported speech in journalistic discourse. Text 15:129-173. 
Wilson, John (1990). Politically speaking. Cambridge, MA: Basil Blackwell.

Wortham, Stanton (2001). Narratives in action. NY: Teachers College Press.

_ — Locher, Michael (1996). Voicing on the news: An analytic technique for studying media bias. Text 16:557-585. 
*We would like to thank the Spencer Foundation and the National Academy of Education for their support of this research through a grant to the first author.

1.We do not claim that reporters always use embedded metapragmatic constructions to solve this problem. Clearly they use many types of linguistic devices to balance the need to appear objective with the desire to report politically charged topics. See Lemke (1998) and van Dijk (1988) for complementary analyses of "semantic" devices used to accomplish this goal. We focus on one type of construction in our study of media bias not because it is necessarily the most common or the best device, but because embedded metapragmatic constructions have a particularly interesting structure. In doing so we follow Verschueren's (1985) advice: instead of simply identifying media bias and indicting the press for it, we study in detail one of the linguistic mechanisms used to convey this bias.

2.Technically speaking, this phrase indexes a particular social group. Speakers in a recognizable social role characteristically use this phrase, and thus the phrase now carries a connection with that group. In Bakhtinian terminology, subsequent uses of that phrase "echo with" the "voices" of military strategists, spokespeople, and aficionados. As we will see, this does not mean that a speaker cannot use the phrase and distance him or herself from the military, but to do so would require work to overcome the presupposed connection.

3.Mayes (1990) provides further reason to doubt the objectivity of direct speech, by reporting that about half the direct quotations in a large sample were wholly or partly fabricated. It would also be unwise to base an argument about human knowledge or human speech in general on the grammatical distinction between direct and indirect quotation, because some languages do not make this distinction (Rumsey 1990).

4.Grammatically speaking, embedded metapragmatic constructions presuppose the three roles of narrator (the one speaking in the narrating event), speaker ${ }_{1}$ and speaker ${ }_{2}$. Thus we have been tempted to call embedded metapragmatics "triple-voicing." Bakhtin's concept of voice, however, is not a grammatical one (cf. especially Bakhtin 1963/1984). A double voiced utterance for Bakhtin contains two live voices, not one perspective parroted by two speakers (as one might encounter in authoritarian discourse, when a speaker quotes another who has been forced to espouse the same position). So embedded metapragmatic constructions have the potential to be triple voiced. They can accomplish the positioning of a narrator with respect to the live voice of a speaker ${ }_{1}$, who is represented positioning him or herself with respect to the live voice of a speaker ${ }_{2}$. But embedded metapragmatic constructions do not necessarily involve three distinct voices.

5.We emphatically do not claim that one embedded metapragmatic construction can suffice to establish voices for candidates and the double voicing of the reporter. Establishing voicing and double voicing generally requires an emergent structure — what Jakobson (1960) and Silverstein (1992) call "poetic structure"- that is cued by various utterances over the course of a conversation. We claim that embedded metapragmatic constructions are often central to these structures and play 
an important role as reporters voice and double voice political candidates. But we do not claim that the cues in embedded metapragmatic constructions alone suffice to accomplish voicing and double voicing in general. See Locher et al. and Wortham et al. (1996) for analyses of more extended segments of newscast discourse, which illustrate how poetic structure emerges from various cues, including those in embedded metapragmatic constructions. See Silverstein (1992) and Wortham (in press) for theoretical descriptions of how voicing and double voicing depend on emergent poetic structures.

6.The brackets here delineate the three presupposed events of speaking. Of course, the reporter does not actually utter I report — we insert it here for clarity.

7.We counted only embedded metapragmatic constructions in news coverage of the political campaign, which took only a few minutes of the evening news each night. Some caution should be used in interpreting these summary statistics, because it is more difficult than one might imagine to distinguish between embedded and simple metapragmatic constructions. Consider the following borderline cases. One reporter described Clinton thus: he went on to suggest the Bush administration is covering up. One could "cover up" either verbally or non-verbally — the latter through actions like destroying evidence or by refusing to comment in an ongoing speech event like an interview. We included this case in our count, because the alleged cover up being referred to involved both verbal and non-verbal acts. On another occasion a reporter said: he is attempting to show that Mr. Bush has questions that he must answer. Answer, more than cover up, is clearly a metapragmatic verb. But the modal here makes clear that Bush has not yet answered. We included this case as well, because of the unambiguously metapragmatic verb used in the embedded clause. A third example: the Clinton campaign says the President is guilty of McCarthyism.

"McCarthyism," like "cover up," while not a canonical metapragmatic expression, generally refers to events of speaking (along with other non-verbal actions). As reflected in these examples, we generally included borderline cases in our counts, when the embedded metapragmatic expression plausibly projected an event of speaking (real or hypothetical) in which the second embedded speaker was positioned or voiced. With respect to the per-newscast frequency, note that embedded metapragmatic constructions tended to come in bunches, with many days having none at all and others having at least half a dozen.

8.That is, the instances in this table represent roughly the same percentage of metapragmatic expressions describing lying and other moral transgressions as the whole data set, and the instances in this table accurately represent that these expressions of lying occur only in the second embedded slot.

9.We can divide the remaining metapragmatic expressions that occur in the first slot into two categories: other minimally presupposing verbs (like takes the view, suggests, etc.); and, more often, expressions that presuppose an argument or conflict between the two candidates.

10.As described by Bell (1991), news stories generally go through several rounds of editing by many different people before they are read on the air. So it may well not have been the reporter's choice of 
metapragmatic expression. It would be an interesting project to trace the genesis of embedded metapragmatic expressions in the writing and editing of news stories, but at the moment we do not have the data to do this. Here we claim merely that the reporter is more responsible for choice of the first than the second metapragmatic expression from the perspective of the audience hearing the report, not that he or she is ultimately responsible for everything in the report. Bell's description of the production of news stories makes it clear that the "bias" in news cannot be accurately conceptualized on the model of a single speaker, because of the multiple agents involved in the production of the final text. This issue takes us beyond the scope of the current article.

11.As Verschueren (1985) describes, objectivity in political reporting is a complicated thing. Political reporters describe campaign events in which people interpret their own and others' acts. Reporters themselves participate in social events, on the campaign trail and in the newsroom, in which they interpret the candidates' (and others') interpretations. Then the audience, in their own varied social situations, interprets the reporters' interpretations of the candidates' interpretations. A full account would have to explore these three layers of interpretation and their interconnections. Toward this end we have done exploratory studies of audience response to the newscasts we have analyzed elsewhere (Locher et al. 1994; Wortham et al. 1996). Preliminary results indicate that audiences (at least audiences of college students) do to reporters what reporters do to the politicians. That is, even thought we did not tell them the purpose of the study, the audiences were looking for media bias and were surprisingly attuned to subtle linguistic cues that reporters use to voice and double voice politicians. The primary difference between our analytic accounts and the audiences' folk accounts was that they most often linked their interpretations of media bias to one or two salient instances in the report, while in our analyses we have looked for more complex patterns of interlocking cues that emerge over a story.

12.Our own position, if examined reflexively, must of course be partly ironic. As analysts we cannot fully emerge from the same sort of social positioning that reporters inevitably find themselves involved in. 


\begin{tabular}{|c|c|}
\hline 1ST METAPRAGMATIC EXPRESSION & 2ND METAPRAGMATIC EXPRESSION \\
\hline said & lying \\
\hline called & liar \\
\hline asserted & lied \\
\hline said & flip-flopped \\
\hline fired back & trying to duck \\
\hline takes the view & waffled \\
\hline suggest & covering up \\
\hline says & smear campaign \\
\hline criticized & failing to address \\
\hline said & lies \\
\hline went after & threatening \\
\hline accused & failure to come clean \\
\hline accusing & flip-flopping \\
\hline said & rave reviews \\
\hline suggested & failed to tell the truth \\
\hline accusing & planting suspicions \\
\hline saying & given conflicting accounts \\
\hline insists & answers \\
\hline claim & assault \\
\hline says & McCarthyism \\
\hline accusing & pandering \\
\hline
\end{tabular}

Table 1. Embedded metapragmatic expressions used in the first and second slots 